\title{
Breast self examination practices among female secondary school teachers in a rural community in Oyo State, Nigeria
}

\author{
Joel Olayiwola Faronbi ${ }^{1}$, Janet Abolade ${ }^{2}$ \\ ${ }^{1}$ Department of Nursing Science, Obafemi Awolowo University, Ile-Ife, Nigeria \\ ${ }^{2}$ University College Hospital, Ibadan, Nigeria \\ Email: faronbiy2k@yahoo.co.uk
}

Received 29 January 2012; revised 8 March 2012; accepted 22 March 2012

\begin{abstract}
The objective of the study was to assess female secondary school teachers' knowledge and attitude of breast self examination (BSE) and to describe the extent of practice of breast self examination among them. This study employed a descriptive design and data was collected with the aid of validated semi structured questionnaire from 100 female teachers in all the five secondary schools in Oko, Oyo State, and analysis was done using Statistical Package for Social Sciences. The result showed that $82 \%$ of the respondents were aware of breast self examination practices and their source of this information was from mass media (55\%) and friends (25\%). Fifty-four respondents had poor knowledge of BSE and $48 \%$ had negative attitude towards practice of BSE and majority $(62 \%)$ had a low practice. The study however, revealed that majority of the respondents who practice BSE do not know what to look for. The results further showed that, there is no significant relationship between age of the respondents and their awareness $\left(X^{2}=8.322 ; p=0.0800 ; d f=4\right)$ and knowledge $\left(X^{2}=\right.$ $14.501 ; p=0.264$ and $\mathrm{df}=8$ ) of breast self examination. This study concluded that there is poor knowledge and attitude towards BSE practice among the secondary school teachers in Oko community and with unsatisfactory practice. It therefore, suggests that breast awareness campaign and self efficacy development is important for teachers in secondary schools to aid early detection and better prognosis of breast cancer in this community, and this will have a multiplier effect on female secondary school girls.
\end{abstract}

Keywords: Breast Self Examination; Knowledge; Attitude; Practice

\section{INTRODUCTION}

Globally, breast cancer is the most common malignant neoplasm among women [1]. Cancer in all forms is responsible for about 12 percent of deaths throughout the world [2]. Breast cancer causes 376,000 deaths a year worldwide; about 900,000 women are diagnosed every year with the disease [1]. This could rates could further increase by $50 \%$ to 15 million [3]. Although the incidence of breast cancer in developing countries is relatively low [4], about $50 \%$ of all cases of breast cancer are diagnosed in these countries [4,5]. Asia and Africa have experienced a more rapid rise in the annual incidence rate of breast cancer than that of North America and Europe [6]. The disease has been reported to have an early onset among Nigerian women [7].

Cancer is a group of diseases that cause any affected part of the body to change and grow out of control. Most types of cancer cells form a lump or mass called tumour, when the tumour metastasize they are transported to another part of the body where they continue to grow [2]. Not all tumours are malignant, some are benign while some are malignant. Benign tumours do not grow and spread the way malignant (cancerous) tumours do, and they are usually not a threat to life [8]. Most types of cancer are named after the part of the body where the cancer first starts. Breast cancer begins in the breast tissues [8]. In breast cancer the cells of the breast grow in a chaotic way. Instead of growing and dividing in a regular and expected order, they grow out of control. If the cancer is not treated, the cells can spread within the breast or even break off and (metastasize) to other parts of the body.

The high incidence of breast cancer necessitates the need for early detection since it aids early initiation of treatment thereby reducing mortality. Dolinsky [9] stated that the important thing any woman can do to decrease her risk of dying from breast cancer is to learn how to perform breast self examination, have a regular physical examination by their physician and have regular mammogram screening. Among these various diagnostic measures put up for detection of breast lumps, breast self examination is the one that can be performed by indi- 
viduals on their own and most lumps are detected by women themselves, and besides, it is cheap [2]. Even though mammography is a better and more efficient way of diagnosing breast cancer, in developing country like Nigeria, clinicians and women still rely on breast examination. This may be due to its availability and very low technicalities.

A breast self examination can help women detect cysts or other benign (noncancerous) breast problems between checkups. It can also help some women detect breast cancer. It is easy to perform breast self-examination, and it only takes a few minutes. Although it might seem strange or inconvenient at first, it is a skill that all women can use throughout life to help ensure good breast health. There is also evidence that most of the early breast tumours are self-discovered and that the majority of early self-discoveries are by breast self examination (BSE) performers [8].

Kayode, Akande and Osagbemi [10] also asserted that despite the advent of modern screening methods, more than $90 \%$ of cases of cancers of the breast are detected by women themselves, stressing the importance of breast self-examination. Okobia et al., [8] also stressed that there is evidence that most of the early breast tumours are self-discovered and that the majority of early selfdiscoveries are by breast self-examination (BSE) performers. Previous studies on cancer detection practices have focused on women in urban and semi urban setting and little or no research have been conducted among women in rural and remote area. In most Nigerian villages, access to health care services, especially comprehensive diagnostic services is very low, if not completely unavailable hence, individual self health empowerment is very important. Female secondary school teachers are not only educators, but serve as role models and change agents who often offer useful counsel on health promotion especially in a very low literate society. Therefore, this study aimed at assessing breast self examination practice among female secondary school teachers in Oko, Oyo State. The objectives of the study are to: assess female secondary school teachers' knowledge of breast self examination, to establish their awareness and sources of information, determine their attitude, and to describe the extent of practice of breast self examination among them.

\section{RESEARCH METHODOLOGY}

The study employed a descriptive quantitative design to assess the knowledge and practice of breast self examination among female teachers in five secondary schools in Oko, Oyo State. Oko is a remote village in Iresa Adu Local Government Area of Oyo State. It has five secondary schools owned by government and private individu- als. The target population comprises all female teachers in the village at the time of data collection. And it includes Baptist Grammar School (42), Muslim Comprehensive High School (27), First Baptist Church Academy (12), Juli Standard Secondary School (19) and Frontier Model College (13). This gives a total of one hundred and three (103) teachers. However, three of them could not be reached as a result of official assignment that made them not to be around.

Data was collected using a self-administered questionnaire developed through extensive literature search. The instrument was tested for validity and reliability before final usage. It consisted of closed-ended questions that were used to collect data that would meet the objectives of the study.

Permission to collect data was obtained from the Local Inspector of Education, Surulere Local Government Area, Iresa Adu. Further permission and approval was requested and obtained from principal of each school before the commencement of the study. Besides, informed consent was obtained from each respondent and they were assured of their confidentiality and anonymity of the information provided.

Data generated for the study was analyzed using Statistical Package for Social Sciences (SPSS version 16). Statistical techniques employed include descriptive statistics (frequency and percentage) and inferential statistics (chi square). Initial analysis was done by generation of frequency tables while further analysis involved crosstabulations to explore statistical relationships between variables.

\section{RESULTS}

One hundred questionnaires were administered to female secondary school teachers and all were returned completed. As presented in Table 1, the age of the respondents ranged from 21 to 45 years with a mean 28 years $( \pm 6.2)$. Thirty-one respondents were between 26 - 30 years of age, majority $(80 \%)$ of the respondents were Yoruba. Similarly, the educational profile revealed that a large proportion (43\%) had National Certificate in Education (NCE) qualification, $46 \%$ were married and $65 \%$ were Christian.

Table 2 revealed that $82 \%$ of the respondent were aware of breast self examination, and their major source of information is from radio and television (55\%) and friends (25\%). Table 3 presents the responses to various questions on BSE. Only 22\% had understanding of what BSE assessment is all about. Although $82 \%$ claimed to have examined their breast before but only $12 \%$ have the correct knowledge that it should be examined monthly and only 16\% knew that it should start from 20 years of age. Furthermore, when asked about the benefits of per- 
Table 1. Socio-demographic characteristics of respondents.

\begin{tabular}{|c|c|c|}
\hline Variables & $\mathbf{n}$ & $\%$ \\
\hline \multicolumn{3}{|l|}{ Age } \\
\hline $21-25$ & 29 & 29 \\
\hline $26-30$ & 31 & 31 \\
\hline $31-35$ & 15 & 15 \\
\hline $36-40$ & 18 & 18 \\
\hline 40 and above & 7 & 7 \\
\hline Total & 100 & 100 \\
\hline \multicolumn{3}{|l|}{ Marital Status } \\
\hline Married & 46 & 46 \\
\hline Single & 42 & 42 \\
\hline Divorced & 2 & 2 \\
\hline Widowed & 10 & 10 \\
\hline Total & 100 & 100 \\
\hline \multicolumn{3}{|l|}{ Religion } \\
\hline Christianity & 65 & 65 \\
\hline Islam & 33 & 33 \\
\hline Traditional & 2 & 2 \\
\hline Total & 100 & 100 \\
\hline \multicolumn{3}{|l|}{ Tribe } \\
\hline Yoruba & 80 & 80 \\
\hline Ibo & 15 & 15 \\
\hline Hausa & 5 & 5 \\
\hline Total & 100 & 100 \\
\hline \multicolumn{3}{|c|}{ Educational Status } \\
\hline N.C.E. & 43 & 43 \\
\hline Polytechnics & 16 & 16 \\
\hline University & 41 & 41 \\
\hline Total & 100 & 100 \\
\hline
\end{tabular}

Table 2. Awareness about breast self examination $(n=100)$.

\begin{tabular}{ccc}
\hline Variable & $\mathbf{n}$ & $\%$ \\
\hline Awareness about BSE & & \\
Yes & 82 & 82.0 \\
No & 18 & 18.0 \\
& & \\
Source of information & 25 & 25.0 \\
Friend & 4 & 4.0 \\
Husband & 55 & 55.0 \\
Radio and Television & 16 & 16.0 \\
Others & & \\
\hline
\end{tabular}

Table 3. Knowledge about breast self examination $(\mathrm{n}=100)$.

\begin{tabular}{|c|c|}
\hline $\begin{array}{l}\text { What do you understand by breast self } \\
\text { examination? }\end{array}$ & Percent \\
\hline $\begin{array}{l}\text { Assessment made on the breast by an individual to } \\
\text { check for lump }\end{array}$ & 22 \\
\hline $\begin{array}{l}\text { An assessment made on the breast by doctor or nurse } \\
\text { to check for lump }\end{array}$ & 61 \\
\hline All of the above & 10 \\
\hline None of the above & 7 \\
\hline \multicolumn{2}{|l|}{ Have you examining your breast before? } \\
\hline Yes & 82 \\
\hline No & 18 \\
\hline \multicolumn{2}{|l|}{ How often do you examine your breast? } \\
\hline Daily & 30 \\
\hline Weekly & 45 \\
\hline Monthly & 12 \\
\hline Bi-monthly & 8 \\
\hline Yearly & 10 \\
\hline \multicolumn{2}{|l|}{$\begin{array}{l}\text { At what period of the cycle do you perform breast } \\
\text { self examination? }\end{array}$} \\
\hline Before menstruation & 42 \\
\hline After menstruation & 20 \\
\hline Any time & 30 \\
\hline No idea & 8 \\
\hline \multicolumn{2}{|l|}{ At what age should breast examination be started? } \\
\hline $\begin{array}{l}\text { Below } 20 \\
\text { Starting from } 20 \\
\text { From } 25 \\
\text { Above } 30\end{array}$ & $\begin{array}{l}25 \\
16 \\
14 \\
45\end{array}$ \\
\hline \multicolumn{2}{|l|}{$\begin{array}{l}\text { What are the advantages are of breast self } \\
\text { examination? }\end{array}$} \\
\hline It helps in early detection of breast lump & 22 \\
\hline $\begin{array}{l}\text { It helps the individual to know the shape and size of } \\
\text { her breasts }\end{array}$ & 18 \\
\hline It is for cosmetic purpose & 36 \\
\hline None of the above & 24 \\
\hline
\end{tabular}

forming BSE, only $22 \%$ understood that it helps in early detection of breast lump, and other described it as follow: $18 \%$ believed that it helps the individual to know the shape and size of her breasts, $36 \%$ described that it is only for cosmetics purpose while $24 \%$ did not have any idea of what it is.

The knowledge, attitude and practice of respondents about breast self examination is presented in Table 4. It showed that more than half (54\%) of the respondent had poor knowledge, a large proportion (48\%) also had poor 
attitude and sixty-two demonstrated a poor practice.

The statistical testing further revealed that there exists no relationship between age of the respondents and their awareness $\left(\mathrm{X}^{2}=8.322, \mathrm{p}=0.0800\right.$ and $\left.\mathrm{df}=4\right)$ and knowledge $\left(X^{2}=14.501 ; p=0.264\right.$ and $\left.d f=12\right)$ of BSE.

\section{DISCUSSION}

The age distribution of respondents ranged from 21 to 42 years. The participants were within the reproductive age, which means they are expected to be knowledgeable and practicing BSE.

Findings from this study showed that there is a high level of awareness of breast self examination (82\%) among the respondents and their major source of information are radio and television and friend (55\%). This supports [11,12] who declared that there is a high awareness of BSE in their studies. Reason for this increased awareness may be due to the fact that there is increase sensitization and mass campaign about BSE in both the print and electronic media on daily basis. Moreover, all the respondents were teachers; this would have given them the opportunity of reading educational materials on BSE.

Oluwatosin \& Oladepo [12] asserted that it is important for individual women to perform breast self examination monthly so that she will become familiar with her own breasts. Findings from this study however, revealed that majority of the teachers (54\%) had poor knowledge of breast self examination. This supports the earlier studies [13] that reported that $75.8 \%$ of women had insufficient knowledge of BSE. This is however, contrary to [7] which found out that nurses possessed adequate know-

Table 4. Knowledge of and attitude towards the practice of breast self examination.

\begin{tabular}{|c|c|c|}
\hline Variables & Frequency & Percentage (\%) \\
\hline \multicolumn{3}{|l|}{ Knowledge } \\
\hline Good & 32 & 32.0 \\
\hline Average & 14 & 14.0 \\
\hline Poor & 54 & 54.0 \\
\hline Total & 100 & 100.0 \\
\hline \multicolumn{3}{|l|}{ Attitude } \\
\hline Good & 24 & 24.0 \\
\hline Fair & 28 & 28.0 \\
\hline Negative & 48 & 48.0 \\
\hline Total & 100 & 100.0 \\
\hline \multicolumn{3}{|l|}{ Practices } \\
\hline Good & 18 & 18 \\
\hline Fair & 20 & 20 \\
\hline Poor & 62 & 62 \\
\hline Total & 100 & 100 \\
\hline
\end{tabular}

ledge of BSE.

Findings from this study further showed that almost half $(48 \%)$ of the respondent had negative attitude towards breast self examination, this is however, contrary to $[10,14]$ who reported that respondents had a healthy attitude to breast cancer screening.

Furthermore findings from this study also showed that BSE was poorly practiced in this study population as revealed by $62 \%$ who did not practice BSE. This supports [10] who reported a low practice of BSE in their study. This is however; contrary to $[7,15,16]$ who reported in their studies, that majority of the respondents practiced BSE.

Furthermore, findings from this study demonstrated that there is no significant relationship between age of the respondents and their awareness about breast self examination $\left(\mathrm{X}^{2}=8.322, \mathrm{p}=0.0800\right.$ and $\left.\mathrm{df}=4\right)$ and knowledge $\left(X^{2}=14.501, p=0.264\right.$ and $\left.d f=8\right)$. This means that the age of the respondents has nothing to do with their awareness and knowledge of breast self examination.

\section{CONCLUSION}

In conclusion, this study has shown that teachers in this community were aware of BSE and their source of information is electronic media and friend. However, they possessed poor knowledge and demonstrated negative attitude towards BSE and their practice was also poor. A very large number who have attempted to practice BSE did it wrongly.

\section{Implication for Nursing}

Teachers constitute one group of professionals who have regular contact not only with their students in schools but with the community members who look at them as change agents and role models. This study has demonstrated that there exists a gap in the knowledge and attitude of teachers towards the practice of breast self examination. If teachers are to fulfill their role as an educator in their various communities, this knowledge gap needs to be filled. Nurses therefore have a mandate to ensuring that teachers are educated on health promotion activities such as BSE.

This could be achieved through designing and implementing an intensive health education programme for female teachers on the necessity and practice of breast self examination. Educational materials such as handbills, poster and leaflets should be freely made available during such teachings so as to facilitate better learning. Nurses could also be involved in advocacy visit to media houses to disseminate appropriate information on breast self examination through radio and television programs. This will raise people's awareness and knowledge on 
breast self examination, its implications and the importance of breast cancer screening. Finally, further research should be conducted to cover an expanse population, this will allow for generalization.

\section{REFERENCES}

[1] World Health Organization (2006). http://www.who.int/cancer/detection/breastcancer/en/inde $\underline{\mathrm{x} . h \mathrm{tml}}$

[2] Park, K. (2007) Park's textbook of preventive and social medicine. 19th Edition, Banarsidas Bhanot Publishers, Jabalpur, 318-327.

[3] World Health Organization (2003) International agency for research on "Cancer World Report".

[4] Ko, C.M., Sadler, G.R., Ryujin, L. and Dong, A. (2003) Filipina American women's breast cancer knowledge, attitudes, and screening behaviors. Biomed Central Public Health, 3, 27.

[5] Haji-Mahmoodi, M., Montazeri, A., Jarvandi, S., Ebrahimi, M., Haghighat, S. and Harirchi I. (2002) Breast selfexamination: Knowledge, attitudes, and practices among female health care workers in Tehran, Iran. Breast Journal, 8, 222-225. doi:10.1046/j.1524-4741.2002.08406.X

[6] Shirazi, M., Champeau, D. and Talebi A. (2006) Predictors of breast cancer screening among immigrant Iranian women in California. Journal of Women's Health, 15, 485-506. doi:10.1089/jwh.2006.15.485

[7] Odusanya, O.O. and Tayo, O.O. (2001) Breast Cancer knowledge, attitudes and practice among nurses in Lagos, Nigeria. Acta Oncologica, 40, 844-848. doi:10.1080/02841860152703472

[8] Okobia, M.N., Bunker, C.H., Okonofua, F.E. and Osime,
U. (2006) Knowledge, attitude and practice of Nigerian women towards breast cancer; a cross sectional study. World Journal of Surgical Oncology, 21, 1-9

[9] Dolinsky, C. (2006) Breast cancer: The basics. http://adventurist1473.multiply.com

[10] Kayode, F.O., Akande, T.M. and Osagbemi G.K. (2005) Knowledge, attitude and practice of breast self examination among female secondary school teachers in Ilorin, Nigeria. European Journal of Scientific Research, 10, 42.

[11] Onyiye, F.J., Zenebo, V.C. and Oboma, Y.I. (2010) Knowledge and practice of breast cancer screening among female students in tertiary institution in Nigeria. Continental Journal of Biomedical Sciences, 75, 82.

[12] Oluwatosin, O.A. and Oladepo, O. (2006) Knowledge of breast cancer and its early detection measures among rural women in Akinyele local government area, Ibadan, Nigeria. BMC Cancer, 6, 271-273.

[13] Heidari, Z., Mahmoudzadeh-Sagheb, H.R. and Sakhavar, N. (2008) Breast cancer screening knowledge and practice among women in southeast of Iran. Acta Medica Iranica, 46, 321-328.

[14] Budden, L. (1995) Young women's breast self-examination knowledge and practice. Journal of Community Health Nursing, 12, 23-32. doi:10.1207/s15327655jchn1201_3

[15] Bassey, R.B., Irurhe, N.K., Olowoyeye, M.A., Adeyomoye, A.A. and Onajole, A.T. (2011) Knowledge, attitude and practice of breast self examination among nursing students in Lagos University Teaching Hospital, Nigeria.

[16] Seah, M. and Tan, S.M. (2007) Am I breast cancer smart? Assessing breast cancer knowledge among healthcare professionals. Singapore Medical Journal, 48, 158-162. 